\title{
Review \\ Protein Kinase C as a Therapeutic Target in Non-Small Cell Lung Cancer
}

\author{
Mohammad Mojtaba Sadeghi ${ }^{1,2}$, Mohamed F. Salama ${ }^{2,3,4}$ (D) and Yusuf A. Hannun ${ }^{1,2,3, *(\mathbb{D})}$ \\ 1 Department of Biochemistry, Molecular and Cellular Biology, Stony Brook University, \\ Stony Brook, NY 11794, USA; mohammad.sadeghi@stonybrook.edu \\ 2 Stony Brook Cancer Center, Stony Brook University Hospital, Stony Brook, NY 11794, USA; \\ mohamed.salama@stonybrookmedicine.edu \\ 3 Department of Medicine, Stony Brook University, Stony Brook, NY 11794, USA \\ 4 Department of Biochemistry, Faculty of Veterinary Medicine, Mansoura University, \\ Mansoura 35516, Dakahlia Governorate, Egypt \\ * Correspondence: yusuf.hannun@stonybrookmedicine.edu
}

Citation: Sadeghi, M.M.; Salama, M.F.; Hannun, Y.A. Protein Kinase C as a Therapeutic Target in Non-Small Cell Lung Cancer. Int. J. Mol. Sci. 2021, 22, 5527. https://doi.org/ $10.3390 /$ ijms 22115527

Academic Editors:

Alexander Schramm and

Marcel Wiesweg

Received: 25 April 2021

Accepted: 20 May 2021

Published: 24 May 2021

Publisher's Note: MDPI stays neutral with regard to jurisdictional claims in published maps and institutional affiliations.

Copyright: (c) 2021 by the authors. Licensee MDPI, Basel, Switzerland. This article is an open access article distributed under the terms and conditions of the Creative Commons Attribution (CC BY) license (https:/ / creativecommons.org/licenses/by/ $4.0 /)$.

\begin{abstract}
Driver-directed therapeutics have revolutionized cancer treatment, presenting similar or better efficacy compared to traditional chemotherapy and substantially improving quality of life. Despite significant advances, targeted therapy is greatly limited by resistance acquisition, which emerges in nearly all patients receiving treatment. As a result, identifying the molecular modulators of resistance is of great interest. Recent work has implicated protein kinase C (PKC) isozymes as mediators of drug resistance in non-small cell lung cancer (NSCLC). Importantly, previous findings on PKC have implicated this family of enzymes in both tumor-promotive and tumor-suppressive biology in various tissues. Here, we review the biological role of PKC isozymes in NSCLC through extensive analysis of cell-line-based studies to better understand the rationale for PKC inhibition. PKC isoforms $\alpha, \varepsilon, \eta, \iota, \zeta$ upregulation has been reported in lung cancer, and overexpression correlates with worse prognosis in NSCLC patients. Most importantly, PKC isozymes have been established as mediators of resistance to tyrosine kinase inhibitors in NSCLC. Unfortunately, however, PKC-directed therapeutics have yielded unsatisfactory results, likely due to a lack of specific evaluation for PKC. To achieve satisfactory results in clinical trials, predictive biomarkers of PKC activity must be established and screened for prior to patient enrollment. Furthermore, tandem inhibition of PKC and molecular drivers may be a potential therapeutic strategy to prevent the emergence of resistance in NSCLC.
\end{abstract}

Keywords: non-small cell lung cancer (NSCLC); targeted therapy; chemotherapy; protein kinase C (PKC); drug resistance; epidermal growth factor receptor (EGFR); tyrosine kinase inhibitors (TKI); enzastaurin

\section{Introduction}

Lung cancer is the most prevalent cancer and the leading cause of cancer-related mortality worldwide, with an estimated 2,093,900 new cases and 1,761,000 deaths annually [1,2]. Due to the initial asymptomatic course of lung cancer, most patients present with locally advanced or metastatic disease at the time of diagnosis. Metastatic lung cancer has significantly limited therapeutic options and is associated with highly unfavorable prognosis. The current clinical outcomes for lung cancer patients are far from satisfactory, and novel treatments must be developed that improve overall survival (OS) [3]. Lung cancer is histologically classified into small cell lung cancer and non-small cell lung cancer (NSCLC). NSCLC accounts for the largest subset of lung cancer cases, roughly 85\%, and is further categorized into adenocarcinoma, squamous cell carcinoma, and large-cell carcinoma [4,5].

Mutational profiling of lung adenocarcinoma patients reveals Kirsten rat sarcoma viral oncogene (KRAS), epidermal growth factor receptor (EGFR), and anaplastic lymphoma kinase $(A L K)$ as the most prominent oncogenic drivers. Other, less common mutations have 
been reported and include $B R A F, P I K 3 C A, M E T, H E R 2, M E K 1$, and NRAS (Figure 1) [6]. Driver mutations define tumor biology and present vulnerabilities that could be exposed via specific inhibition to suppress tumor growth. Driver-directed therapeutics have heralded impressive clinical outcomes, drastically changing the treatment course and the progressionfree survival (PFS) of patients who would otherwise be given standard chemotherapy with an estimated median survival of under 12 months [7]. Critically, patients with appropriate biomarkers initially show remarkable responses to targeted therapy. However, nearly all patients relapse with tumors that are no longer sensitive to original treatment, and such an acquired resistance greatly hinders the clinical outcomes of lung cancer patients. Therefore, understanding the mechanisms that drive the emergence of resistance is of interest, and therapeutic approaches that overcome resistance are essential [8].

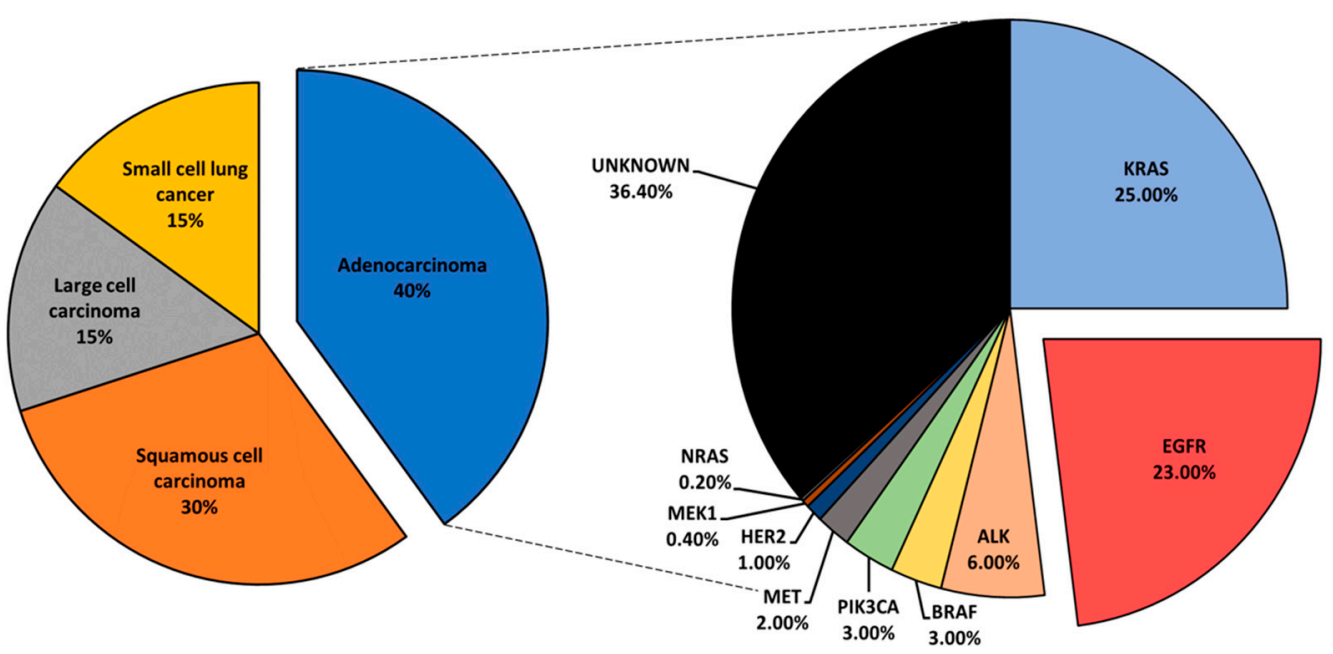

Figure 1. An overview of lung cancer histology and driver mutations in adenocarcinoma patients.

In addition to the commonly identified driver mutations, other upregulated mediators have been observed in NSCLC. Interestingly, elevated protein kinase C (PKC) isoforms $\alpha, \varepsilon, \eta$, and $\iota$ have been observed in NSCLC and associated with poor prognosis, hinting at a potential role in mediating tumorigenesis [9]. In this review, we will discuss the consequence of PKC regulation in the context of NSCLC, with hopes to elucidate the potential benefits of inhibiting PKCs, likely in tandem with targeted therapy.

\section{The Protein Kinase C Family}

The family of PKC has been extensively reviewed over the years [10-17]. Briefly, PKCs were initially discovered in 1977 by the group of Yasutomi Nishizuka [18]. Later characterization of this novel kinase led to the discovery of three classes: classical $(\alpha, \beta 1, \beta 2$, $\gamma)$, novel $(\delta, \varepsilon, \eta, \theta)$, and atypical $(\zeta, \iota)$ PKCs [19-25]. Biochemical analysis of PKCs revealed a highly conserved $\mathrm{C}$-terminal catalytic domain, with a variable $\mathrm{N}$-terminal regulatory domain (Figure 2) [26]. Identification of PKC as a direct effector of diacylglycerol (DAG) defined the primary second messenger function of DAG and connected PKC to the phosphatidylinositol (PI) cycle of signaling [27]. Cytosolic concentrations of second messenger activators of PKC, DAG and calcium, are mediated by phospholipase $C$, which cleaves phosphatidylinositol 4,5-bisphosphate $\left(\mathrm{PIP}_{2}\right)$ to generates DAG and inositol trisphosphate $\left(\mathrm{IP}_{3}\right) . \mathrm{IP}_{3}$ further regulates cytosolic calcium levels. The discovery of PKC activation by tumor-promoting agent phorbol 12-myristate 13-acetate (PMA) in 1982 [28] drew attention to this family of kinases based on the plethora of cell biologic responses to PMA and other phorbol esters, warranting extensive research that implicated PKC isozymes in various pathologies, including cancer, heart disease, diabetes, and several neurological diseases [10-16]. It should be noted that the atypical PKCs, $\mathrm{PKC} \mathrm{L}$ and $\mathrm{PKC} \zeta$, are not targets for either DAG or phorbol esters. 


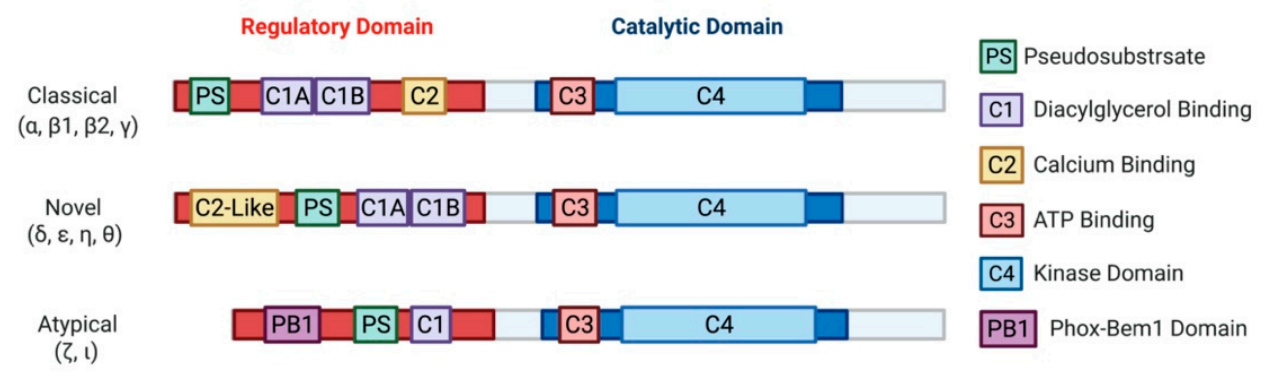

Figure 2. A schematic representation of PKC subfamily structural domains. Distinct PKC isozymes are categorized into classical, novel, or atypical PKCs based on N-terminal regulatory domain structure and have conserved C1-4 domains. Classical PKC $\alpha, \beta 1, \beta 2, \gamma$ are activated by DAG and calcium through binding with $\mathrm{C} 1 \mathrm{~A}-\mathrm{C} 1 \mathrm{~B}$ and $\mathrm{C} 2$ domain, respectively. Novel PKC isoforms $\delta, \varepsilon, \eta$, $\theta$ are DAG dependent but calcium independent for their activation, as the C2-like domain cannot bind calcium. Atypical PKC $\zeta$, ı do not respond to calcium or DAG. All PKC isozymes have a pseudosubstrate (PS) domain involved in kinase auto-inhibition. The C-terminal catalytic domain is highly homologous between all the PKC isozymes and consists of an ATP binding C3 domain and a C4 kinase domain.

In the context of cancer, PKCs are known to regulate several cellular processes, including proliferation, cell cycle progression, angiogenesis, metastasis, apoptosis, and drug resistance (Figure 3) [16]. Contrary to findings implicating PKCs as promoters of cancer progression, a separate body of work has established PKCs as tumor suppressors in various tissues by inducing differentiation and inhibiting anchorage-independent growth, migration, and metastasis. $[17,29,30]$. Contradictory results on the biological role of PKCs have led to the conclusion that PKC-mediated biology is highly tissue- and isozyme-specific [31].

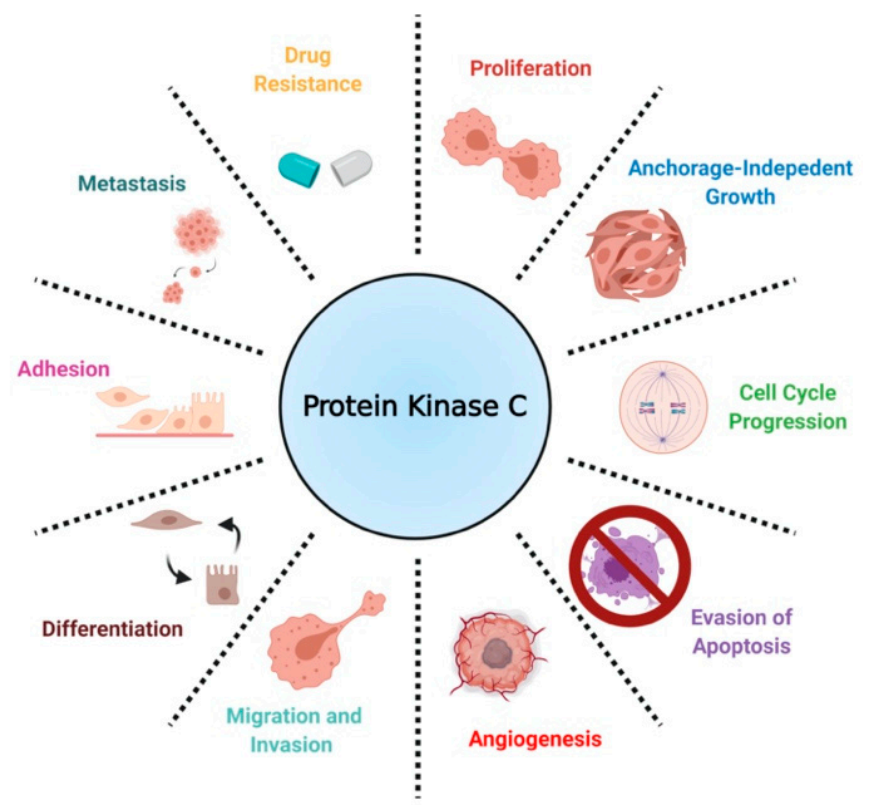

Figure 3. A scheme defining the biological roles of PKC in NSCLC.

\section{Expression, Biological Role, and Prognosis of Protein Kinase C in NSCLC}

Bioinformatic analysis using gene expression databases and immunohistochemistry (IHC) analysis of patient tissues have revealed the upregulation of several PKC isoforms in NSCLC compared to normal lung epithelium.

PKC $\alpha$ is highly expressed in NSCLC. Expression is higher in adenocarcinoma than squamous cell carcinoma [32]. NSCLC cell lines H1355, H157, H1155, H1703, and A549 showed elevated PKC $\alpha$ levels compared to normal human bronchial epithelial cells [33]. 
Elevated PKC $\alpha$ activity has been observed in A549, PC-9, PC-14, and RERF-LC-MS NSCLC cell lines [34]. Notably, a recent study reported significantly worse OS in lung adenocarcinoma patients expressing relatively high PKC $\alpha$ protein levels [35]. In agreement with this finding, a vast body of work on PKC $\alpha$ has implicated the kinase as a promoter of tumorigenesis in KRAS or EGFR mutant NSCLC. Antisense oligonucleotide-mediated suppression of PKC $\alpha$ demonstrated antitumor activity in LTEPa- 2 and A549 by reducing proliferation and invasive phenotype in tissue culture [36,37]. Furthermore, antisense downregulation of PKC $\alpha$ inhibited tumor growth of A549-inoculated xenografts in vivo [38]. In addition to positively regulating cell proliferation and migration, $\mathrm{PKC} \alpha$ is more specifically implicated in cell cycle progression and apoptosis in NSCLC. Antisense downregulation of PKC $\alpha$ and $\theta$ in $\mathrm{H} 23$ cells resulted in an increased expression of p21, leading to G1 arrest in a p53-independent manner [39]. PKC $\alpha$ has also been implicated in drug sensitivity and resistance acquisition and was reported to mediate doxorubicin sensitivity by phosphorylation of RLIP76 in NSCLC [40,41]. Interestingly, a separate study has linked PKC $\alpha$ to multi-drug resistance gene $M D R 1$, suggesting a potential mechanism by which PKC mediates drug sensitivity [42]. The PKC inhibitor, chelerythrine chloride, decreased PKC $\alpha$ mRNA expression and protein levels and sensitized cisplatin-resistant A549 to cisplatin [43]. However, PKC and drug sensitivity findings are not limited to PKC $\alpha$, but are also reported for other isoforms [44]. Upregulation, increased activity, and tumor-promoting properties of PKC $\alpha$ deem the kinase as a potential marker and therapeutic target in NSCLC patients. Notably, the detection of activated PKC $\alpha$ in serum has been reported to be a potential prognostic marker for lung cancer [45].

PKC $\delta$ has been suggested as a therapeutic target for NSCLC. In NSCLC cells with mutant $K R A S$, targeting PKC $\delta$ has been shown to inhibit invasion, migration, and colony formation [46]. Moreover, inhibiting PKC $\delta$ in NSCLC cells promotes drug-induced apoptosis [33]. In H1299, HSP27 and PKC $\delta$ heptapeptide interaction has been linked to drug and radiation resistance [47].

PKC $\varepsilon$ overexpression has been detected in $>90 \%$ of NSCLC patient samples via IHC [48]. Low expression of PKC $\varepsilon$ in healthy tissue has made the isozyme a potential cancer marker [49]. Functionally, PKC $\varepsilon$ has been linked to enhanced proliferation, cell cycle progression, migration, and evasion of apoptosis in NSCLC. Ectopic expression of dominant-negative kinase-deficient $\mathrm{PKC} \varepsilon$ demonstrated significantly reduced proliferation and impaired anchorage-independent growth in H358, H460, H23, and H157 when compared to vector controls. This was accompanied by G1 arrest as a consequence of enhanced p21 inactivation of cdk2 [48]. Molecular and pharmacological inhibition of PKCE impaired invasiveness of A549 cells in vitro. Knockdown of PKC $\varepsilon$ by an isoform-specific siRNA downregulated expression and secretion of several metalloproteases, suggesting a possible mechanism for reduced migration. In vivo metastasis models using a stable shRNA-mediated depletion of PKC $\varepsilon$ in A549 have confirmed in vitro findings. Separately, pharmacological inhibition of PKC $\varepsilon$ using isoform-specific peptide inhibitor $\varepsilon$ V1-2 was reported to reduce $\mathrm{H} 358$ tumor growth in athymic nude mice [50]. PKC $\varepsilon$ downregulation impaired the metastatic potential of intravenously inoculated A549 cells [51]. Furthermore, PKC $\varepsilon$ downregulation has been linked to apoptosis; PKC $\varepsilon$-depleted cells expressed elevated levels of several pro-apoptotic genes, such as Bak, and showed a decrease in anti-apoptotic Bcl-2 mRNA expression. Interestingly, a separate study on miR-143, shown to specifically regulate $\mathrm{PKC} \varepsilon$, also confirmed the tumor-promoting role of $\mathrm{PKC} \varepsilon$ and its implication in apoptosis. miR-143 has been reported to be downregulated in lung cancer, and its suppression enhanced the proliferation and allowed the evasion of apoptosis in A549 and Calu-1 cells [52]. These findings elucidate the potential therapeutic advantage of $\mathrm{PKC} \varepsilon$ inhibition in a subset of lung cancer patients overexpressing the kinase.

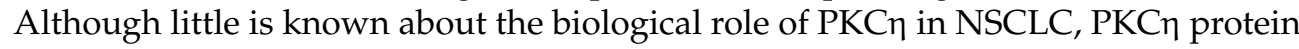
levels correlated positively with disease stage, and its overexpression has been linked to poor prognosis in lung cancer [53]. A previous study reported an increased risk of death within the first year of diagnosis in NSCLC patients with relatively higher levels 


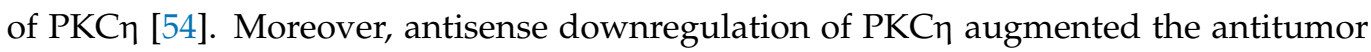
effects of vincristine and paclitaxel in A549 cells [44]. These findings warrant further investigation into the biological consequence of PKC $\eta$ regulation in NSCLC to expose potential vulnerabilities [55].

PKC $\mathrm{I}$ is similarly overexpressed in NSCLC tissues compared to normal lung epithelium [56-60]. Western blot analysis of NSCLC cell lines A549, H520, H1299, H292, ChaGo, and Sk-Mes1 showed high PKCı protein levels [59,61]. Overexpression of PKCı correlated with poor OS of lung adenocarcinoma patients [62]. Moreover, there is a positive relationship between PKCı expression and glucose metabolism. Patients with a higher expression of PKC $\mathrm{l}$ and glucose transporter GLUT1 showed a poorer prognosis [63]. Elevated expression of PKCı mRNA and protein levels in NSCLC have been attributed to PRKCI gene amplification [57]. Importantly, PKCı has been implicated in NSCLC growth, migration, and anti-apoptotic signaling. Stable expression of kinase-deficient PKC $\mathrm{L}$ impaired anchorage-independent growth of A549, H1299, and ChaGo cells [57,61]. In agreement with this finding, a study identifying targets of $\mathrm{PKC} \mathrm{\iota}$ revealed that the downregulation of four downstream effector genes, COPB2, ELF3, RFC4, and PLS1, suppressed the transformed phenotype of A549 [64]. PKCᄂ-dependent activation of Rac1 resulted in subsequent activation of the PAK/MEK/ERK pathway. Constitutively active Rac1 restored anchorageindependent growth of A549 stably expressing kinase-inactive $\mathrm{PKCl}$ [61]. A subsequent study noted Ect2 as another effector, regulated by PKCl. Importantly, the PKCı-regulated phosphorylation of Ect2 was a critical event for the promotion of anchorage-independent growth of H1703 cells [65]. Notably, a study looking at lung adenocarcinoma tissue reported increased PKCı expression in invasive lesions [62]. Pharmacological inhibition of PKC 1 using atypical PKC inhibitor DNDA increased the apoptosis of H1299 and A549 cells, accompanied by a decrease in pro-survival Bcl-2 and an increase in cleaved caspase-3 [59]. Additionally, $\mathrm{PKC} \mathrm{\iota}$ regulates Bcl-x splicing, promoting survival through anti-apoptotic Bcl-x(L) expression [66]. In a recent study, PKCı was shown to phosphorylate ELF3 transcription factor, driving the expression of $\mathrm{NOTCH} 3$, which, in turn, induced stemness and promoted lung tumor formation in KRAS-mutant NSCLC [67]. These findings provide compelling evidence linking PKCı to invasion and metastasis in NSCLC. Therefore, the inhibition of PKCı may be a rational approach to suppressing NSCLC, particularly in specific contexts such as mutant KRAS-expressing lung adenocarcinoma [68]. Inhibition of the PKCL-PAK1 pathway significantly reduced cell viability and colony formation of HCC827, H23, and H520 cells, showing efficacy not only in mutant KRAS cells, but also mutant EGFR ( $\triangle E G F R$ ) cell lines [69]. Importantly however, lung adenocarcinoma may develop through both $\mathrm{PKCl}$-dependent and $\mathrm{PKCl}$-independent pathways [70]. Therefore, it is critical to limit PKCı-targeted approaches to PKCı-dependent tumors.

More recently, PKC $\zeta$ upregulation has also been observed in NSCLC. PKC $\mathrm{L}$ and PKC $\zeta$ are both reported to be downstream effectors of YAP, which regulates the phosphorylation of both atypical PKCs, promoting lung adenocarcinoma tumorigenesis [60]. The specific inhibition of $\mathrm{PKC} \zeta$ was previously shown to regulate NSCLC chemotaxis [71]. Since evidence associates both $\iota$ and $\zeta$ isoforms with pro-invasive biology in NSCLC, atypical PKC inhibition may be a promising therapeutic approach to impair proregression of lung cancer in patients with elevated or activated PKCı and PKC $\zeta$.

Very little is known about the biological roles of PKC $\beta 1, \beta 2, \gamma, \theta$ in NSCLC. PKC $\beta$ promotes angiogenesis in glioblastoma, breast, ovarian, and prostate cancer [72-74]. Additionally, PKC $\beta 2$ is highly expressed in chronic lymphocytic leukemia and chronic myelogenous leukemia, where the kinase suppresses anti-apoptotic signals [75-78]. PKC $\gamma$ expression is mainly limited to neuronal tissues [79]. Furthermore, novel PKC isoform $\theta$ is primarily expressed in hematopoietic cells [80,81]. The expression and known biological roles of PKCs in NSCLC are summarized in Table 1. 
Table 1. Proposed biological roles of distinct PKC isozymes in NSCLC.

\begin{tabular}{ccc}
\hline Isozyme & Biological Roles & References \\
\hline PKC $\alpha$ & $\begin{array}{c}\text { Promotes proliferation, invasion, migration, cell cycle } \\
\text { progression, evasion of apoptosis, drug resistance }\end{array}$ & {$[36-42,82,83]$} \\
PKC $\beta_{1}, \beta_{2}$ & Unknown \\
PKC $\gamma$ & Not expressed \\
PKC $\delta$ & Mediates drug sensitivity, invasion, cell survival & \\
& Promotes proliferation, invasion, migration, cell cycle & {$[33,46,47,82,84]$} \\
PKC $\varepsilon$ & progression, anchorage-independent growth, evasion of & apoptosis \\
PKC $\eta$ & Mediates drug sensitivity & Not expressed \\
PKC $\theta$ & Chemotaxis & {$[48,50-52]$} \\
PKC $\zeta$ & Promotes proliferation, invasion, migration, \\
PKC $\iota$ & anchorage-independent growth, evasion of apoptosis, & {$[57,61-69]$} \\
& stemness, glucose metabolism & \\
\hline
\end{tabular}

\section{Therapeutic Approaches Targeting PKCs in NSCLC}

PKCs have been targeted alone or in combination with other agents in clinical trials through the use of potent activators, antisense oligonucleotides, and specific/ non-specific kinase inhibitors.

The most common clinical and pre-clinical approach in regulating PKC activity is by small-molecule inhibition. ATP-competitive PKC inhibitors are mostly non-specific and show off-target effects on alternate PKC isoforms and other closely related serine/threonine kinases. Lack of isozyme-specific inhibitors is a critical limitation associated with this approach. Enzastaurin, a PKC $\beta$ inhibitor with in vitro IC50 for PKC $\alpha: 39 \mathrm{nM}, \mathrm{PKC} \beta: 6 \mathrm{nM}$, PKC $\gamma: 83 \mathrm{nM}, \mathrm{PKC}_{\varepsilon}: 110 \mathrm{nM}$, is one of the best-studied inhibitors in NSCLC [85]. Enzastaurin treatment of NSCLC cells H520, Calu1, Calu3, and Calu6 impaired colony-forming capability at clinically attainable concentrations [86]. Two separate phase I clinical trials reported favorable toxicity profiles for enzastaurin $[87,88]$. Enzastaurin as second- or third-line treatment of NSCLC patients resulted in disease stabilization of a small subset of patients (13\%) enrolled in the clinical trial [89]. As enzastaurin was well-tolerated in previous studies, further combination of the inhibitor with cytotoxic agents was recommended. Enzastaurin and pemetrexed synergistically inhibited cell cycle progression, enhanced apoptosis, and modulated signaling by reducing AKT phosphorylation and VEGF expression in A549 and SW1573 cells [90]. Enzastaurin, in combination with pemetrexed, was well tolerated in a phase I clinical trials and demonstrated therapeutic efficacy as second-line treatment for patients with advanced NSCLC [91]. Although well-tolerated, enzastaurin and cisplatin-pemetrexed combination as a first-line treatment did not improve PFS or OS of NSCLC patients according to two independent phase II clinical trials [92,93]. In another clinical study assessing PKC inhibitor efficacy in combination with chemotherapy, enzastaurin did not add to the antitumor effects of pemetrexed-carboplatin [94]. A subsequent meta-analysis evaluating additive effects of PKC inhibitors in combination with chemotherapy reported no significant improvement in PFS and OS across all studies and noted additional toxic effects with PKC inhibition [95]. Despite showing pre-clinical success, PKC inhibitors have failed to provide significant benefits in clinical trials. This inefficacy may be explained by the lack of patient stratification based on PKC expression in the clinical trials described above. Most in vitro and in vivo models were conducted on cells with elevated PKC. However, no effort was made to test patients enrolled in clinical trials for PKC levels or predictive biomarkers of PKC activity. Although many factors could explain the discrepancy between pre-clinical and clinical studies, patient treatment without molecular testing is not an optimal approach to assess PKC inhibitor efficacy. It may also be possible that the cytostatic effects of enzastaurin limit the therapeutic potential of chemotherapeutic agents, thus demonstrating little efficacy, as seen in the combination treatment trials described above. 
Tumor-promoting phorbol ester 12-O-tetradecanoyl- phorbol-13-acetate (TPA), bryostatin-1, and bryostatin-2 are potent activators of PKCs. These activators mimic DAG by binding to the C1 domain of classical and novel PKCs [28]. Unlike DAG, however, these activators are not readily metabolized and result in prolonged activation of the isozymes [96]. Bryostatin-mediated activation of PKCs (and less so with TPA) results in the acute degradation of some PKCs following ubiquitination, leading to growth arrest [97,98]. Several studies reported that the treatment of A549 cells with PKC activators results in growth arrest, accompanied by reduced PKC levels and activity [99-103]. TPA was shown to induce G1 arrest in H358 [104] and increased senescence-associated- $\beta$ galactosidase marker [105]. Importantly, neither PKC protein nor activity was measured in these studies; therefore, it is not clear if these findings are due to PKC activation or its downregulation following prolonged activation via TPA as previously reported. PKC activators have demonstrated impressive growth suppression of NSCLC cell lines in vitro and have prolonged OS in vivo [106]. Unfortunately, however, bryostatin-1, administered in combination with paclitaxel, showed no significant benefit in patients with NSCLC and showed unfavorable toxicity profiles [107].

Pre-clinical models using antisense oligonucleotide-mediated suppression of PKC $\alpha$ demonstrated significantly impaired NSCLC tumor growth [36-38]. In addition, the antisense inhibition of PKC $\alpha$ in subcutaneously injected $\mathrm{H} 460$ cells enhanced the antitumor effects of cisplatin [108]. Separately, knockdown of PKC $\alpha$ sensitized cells to several anticancer drugs, including carboplatin and doxorubicin [40,42]. These findings provided a rationale for antisense-directed therapy against PKC $\alpha$ in clinical trials. Initially, a phase I/II study using a PKC $\alpha$ antisense inhibitor LY900003 exhibited antitumor activity when administered in combination with cisplatin and gemcitabine [109]. On the other hand, phase II and phase III clinical trials using a PKC $\alpha$-specific antisense inhibitor aprinocarsen, in combination with chemotherapy, did not show significant survival benefits and exhibited additional toxic effects [110-112]. However, it is worth mentioning that the patients enrolled in these studies were not selected or based on any biomarkers that indicated the prevalence of PKC $\alpha$ overexpression or increased activity. Therefore, the obtained results may not accurately depict therapeutic efficacy as selection of a more appropriate patient cohort is necessary. It has become increasingly clear that, in assessment of targeted therapy, patients must be selected based on host tumor expression of the targeted aberrant gene.

\section{PKC-Mediated Resistance Acquisition and Drug Sensitivity in NSCLC}

In addition to the already described biology, PKCs appear to play a role in mediating sensitivity to cytotoxic agents and targeted therapy based on in vitro models. More recent findings suggest that PKCs may also play a crucial role in mediating resistance to tyrosine kinase inhibitors (TKI). One study reported that erlotinib-resistant H1650-M3 cells expressed significantly higher PKC $\alpha$ and had lower PKC $\delta$ mRNA levels relative to the parental H1650. RNAi and small molecule inhibition of PKC $\alpha$ sensitized H1650-M3 to erlotinib, a TKI inhibitor of $\triangle E G F R$. Importantly, however, a viral-mediated stable overexpression of PKC $\alpha$ did not affect $\mathrm{H} 1650$ sensitivity to erlotinib. This strongly suggests that PKC $\alpha$ alone is not sufficient to induce erlotinib resistance. On the other hand, viral-mediated overexpression of PKC $\delta$ moderately increased H1650-M3 sensitivity to erlotinib [82]. A subsequent study combining PKC inhibitor chelerythrine chloride and erlotinib in the treatment of NSCLC A549 and SK-MES1 cells reported a significant synergy in impairing cell viability, colony formation, tumor growth in xenografts, and enhanced apoptosis. Importantly, however, the concentrations of erlotinib used in the experiments $(2.5-20 \mu \mathrm{M})$ typically exceeded the therapeutic range $(1-2 \mu \mathrm{M})$, and the cell lines used in the study have wild-type EGFR [83]. A more recent study evaluating EGFR-TKI resistance reported PKC $\delta$ to be necessary and sufficient to induce resistance, and downregulation of the kinase via molecular and pharmacological approaches sensitized TKI-resistant cells to erlotinib. Although contradictory to the previous study in H1650-M3, an shRNA-mediated downregulation of PKC $\delta$ sensitized H1650 and TKI-resistant HCC827-GR cells to gefitinib, another EGFR TKI. Importantly, 
ectopic expression of PKC $\delta$ was sufficient to induce resistance in TKI-sensitive HCC827 and H3255. Mutations in the nuclear localization signal that sequestered PKC $\delta$ in the cytoplasm impaired $\mathrm{PKC} \delta$ - induced gefitinib resistance and attenuated phosphorylation of ERK, AKT, and RelA in isolated nuclear fractions. Clinically, PKC $\delta$ upregulation correlated negatively with OS in TKI-treated $\triangle E G F R$ NSCLC patients [84]. Interestingly, our recently published work has demonstrated that there is a $\triangle E G F R$-independent selection for high PKC $\alpha$ protein expression in NSCLC, and a $\triangle E G F R$-dependent activation of PKC $\alpha$ that translates to constitutive downstream signaling to AKT/mTOR pathway [113]. In $B R A F / K R A S$ mutant NSCLC, PKC $\alpha$ was shown to modulate sensitivity to chemotherapy via mediating MDR1 expression and RLIP76 phosphorylation (Figure 4) [40-42]. These findings suggest that PKC $\alpha$ and $\delta$ inhibition, in the context of mutant driver genes such as EGFR and KRAS, may be a novel approach to address TKI-sensitivity and resistance to chemotherapy in NSCLC.

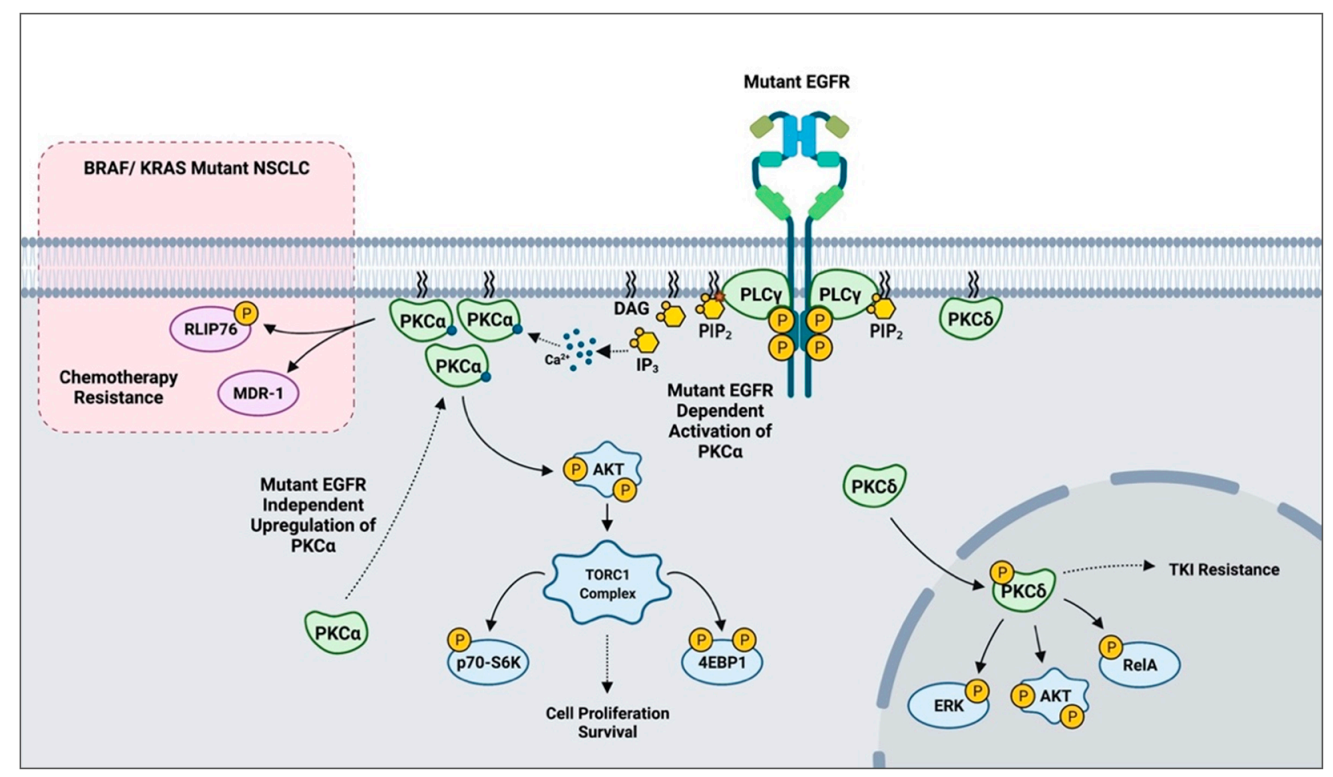

Figure 4. A scheme outlining PKC-mediated drug resistance in EGFR and KRAS mutant NSCLC.

\section{Conclusions}

PKC mRNA and protein levels are shown by several reports to be upregulated in NSCLC, and specific isozymes have been implicated as mediators of drug sensitivity in NSCLC. The implication of these isozymes in tumor-promoting biology and drug resistance strongly suggests that PKC inhibition may be an effective therapeutic approach for NSCLC. Despite showing impressive in vitro and in vivo antitumor effects, PKC inhibitors failed to significantly improve clinical outcomes in NSCLC [114]. This could be partly attributed to the lack of appropriate biomarkers for PKC inhibitor efficacy. Therefore, to effectively assess PKC inhibitor efficacy in NSCLC, future clinical trials should be focused on patients with upregulated PKC levels and the relevant biomarkers of increased PKC activity. More importantly, recent research has shown that specific PKC isozymes may play a role in mediating resistance acquisition to TKI and chemotherapeutic agents in NSCLC. Although approaches targeting PKCs alone in NSCLC have yielded unsatisfactory results, it may be plausible that the inhibition of PKCs, in conjugation with other driver-targeted treatment, may present a potential benefit in overcoming resistance acquisition to cancer therapy.

Author Contributions: Conceptualization, M.M.S. and Y.A.H.; methodology, M.M.S.; software, M.M.S.; validation, M.M.S., M.F.S. and Y.A.H.; formal analysis, M.M.S.; investigation, M.M.S.; resources, M.M.S.; data curation, M.M.S. and M.F.S.; writing—original draft preparation, M.M.S.; writing—review and editing, M.F.S. and Y.A.H.; visualization, M.M.S.; supervision, M.F.S. and Y.A.H.; 
project administration, Y.A.H.; funding acquisition, Y.A.H. All authors have read and agreed to the published version of the manuscript.

Funding: This research was funded by Department of Veterans Affairs, grant number I01 BX004621.

Acknowledgments: The figures presented in this review were created using BioRender.com.

Conflicts of Interest: The authors declare no conflict of interest. The funders had no role in the design of the study; in the collection, analyses, or interpretation of data; in the writing of the manuscript, or in the decision to publish the results.

\section{References}

1. Bray, F.; Ferlay, J.; Soerjomataram, I.; Siegel, R.L.; Torre, L.A.; Jemal, A. Global cancer statistics 2018: GLOBOCAN estimates of incidence and mortality worldwide for 36 cancers in 185 countries. CA Cancer J. Clin. 2018, 68, 394-424. [CrossRef] [PubMed]

2. Siegel, R.L.; Miller, K.D.; Jemal, A. Cancer statistics, 2019. CA Cancer J. Clin. 2019, 69, 7-34. [CrossRef]

3. Molina, J.R.; Yang, P.; Cassivi, S.D.; Schild, S.E.; Adjei, A.A. Non-small cell lung cancer: Epidemiology, risk factors, treatment, and survivorship. Mayo Clin. Proc. 2008, 83, 584-594. [CrossRef]

4. Zheng, M. Classification and pathology of lung cancer. Surg. Oncol. Clin. 2016, 25, 447-468. [CrossRef] [PubMed]

5. Cruz, C.S.; Tanoue, L.T.; Matthay, R.A. Lung cancer: Epidemiology, etiology, and prevention. Clin. Chest Med. 2011, 32, 605-644. [CrossRef] [PubMed]

6. Kris, M.G.; Johnson, B.E.; Kwiatkowski, D.J.; Iafrate, A.J.; Wistuba, I.I.; Aronson, S.L.; Engelman, J.A.; Shyr, Y.; Khuri, F.R.; Rudin, C.M.; et al. Identification of driver mutations in tumor specimens from 1000 patients with lung adenocarcinoma: The NCI's Lung Cancer Mutation Consortium (LCMC). J. Clin. Oncol. 2011, 29, CRA7506. [CrossRef]

7. Zhou, C.; Wu, Y.L.; Chen, G.; Feng, J.; Liu, X.Q.; Wang, C.; Zhang, S.; Wang, J.; Zhou, S.; Ren, S.; et al. Erlotinib versus chemotherapy as firstline treatment for patients with advanced EGFR mutation-positive non-small-cell lung cancer: A multicentre, open-label, randomized, phase 3 study. Lancet Oncol. 2011, 12, 735-742. [CrossRef]

8. Jackman, D.; Pao, W.; Riely, G.J.; Engelman, J.A.; Kris, M.G.; Jänne, P.A.; Lynch, T.; Johnson, B.E.; Miller, V.A. Clinical definition of acquired resistance to epidermal growth factor receptor tyrosine kinase inhibitors in non-small-cell lung cancer. J. Clin. Oncol. 2010, 28, 357-360. [CrossRef]

9. Kang, J.H. Protein kinase C (PKC) isozymes and cancer. New J. Sci. 2014, 2014, 1-36. [CrossRef]

10. Singh, R.M.; Cummings, E.; Pantos, C.; Singh, J. Protein kinase C and cardiac dysfunction: A review. Heart Fail. Rev. 2017, 22, 843-859. [CrossRef]

11. Marrocco, V.; Bogomolovas, J.; Ehler, E.; dos Remedios, C.G.; Yu, J.; Gao, C.; Lange, S. PKC and PKN in heart disease. J. Mol. Cell. Cardiol. 2019, 128, 212-226. [CrossRef] [PubMed]

12. Evcimen, N.D.; King, G.L. The role of protein kinase C activation and the vascular complications of diabetes. Pharmacol. Res. 2007, 55, 498-510.

13. Geraldes, P.; King, G.L. Activation of protein kinase C isoforms and its impact on diabetic complications. Circ. Res. 2010, 106, 1319-1331. [CrossRef]

14. Saxena, A.; Scaini, G.; Bavaresco, D.V.; Leite, C.; Valvassoria, S.S.; Carvalho, A.F.; Quevedo, J. Role of protein kinase C in bipolar disorder: A review of the current literature. Mol. Neuropsychiatry 2017, 3, 108-124. [CrossRef] [PubMed]

15. Alfonso, S.I.; Callender, J.A.; Hooli, B.; Antal, C.E.; Mullin, K.; Sherman, M.A.; Lesné, S.E.; Leitges, M.; Newton, A.; Tanzi, R.E.; et al. Gain-of function mutations in protein kinase $\mathrm{C} \alpha(\mathrm{PKC} \alpha)$ may promote synaptic defects in Alzheimer's disease. Sci. Signal. 2016, 9, ra47. [CrossRef] [PubMed]

16. Koivunen, J.; Aaltonen, V.; Peltonen, J. Protein kinase C (PKC) family in cancer progression. Cancer Lett. 2006, 235, 1-10. [CrossRef] [PubMed]

17. Newton, A.C. Protein kinase C as a tumor suppressor. Semin. Cancer Biol. 2018, 48, 18-26. [CrossRef]

18. Inoue, M.; Kishimoto, A.; Takai, Y.; Nishizuka, Y. Studies on a cyclic nucleotide-independent protein kinase and its proenzyme in mammalian tissues. II. Proenzyme and its activation by calcium-dependent protease from rat brain. J. Biol. Chem. 1977, 252, 7610-7616. [CrossRef]

19. Parker, P.J.; Coussens, L.; Totty, N.; Rhee, L.; Young, S.; Chen, E.; Stabel, S.; Waterfield, M.D.; Ullrich, A. The complete primary structure of protein kinase C-The major phorbol ester receptor. Science 1986, 233, 853-859. [CrossRef] [PubMed]

20. Coussens, L.; Parker, P.J.; Rhee, L.; Yang-Feng, T.L.; Chen, E.; Waterfield, M.D.; Francke, U.; Ullrich, A. Multiple, distinct forms of bovine and human protein kinase $C$ suggest diversity in cellular signaling pathways. Science 1986, 233, 859-866. [CrossRef]

21. Jaken, S.; Kiley, S.C. Purification and characterization of three types of protein kinase C from rabbit brain cytosol. Proc. Natl. Acad. Sci. USA 1987, 84, 4418-4422. [CrossRef] [PubMed]

22. Ohno, S.; Kawasaki, H.; Imajoh, S.; Suzuki, K.; Inagaki, M.; Yokokura, H.; Sakoh, T.; Hidaka, H. Tissue-specific expression of three distinct types of rabbit protein kinase C. Nature 1987, 325, 161. [CrossRef] [PubMed]

23. Kubo, K.; Ohno, S.; Suzuki, K. Primary structures of human protein kinase C $\beta I$ and $\beta I I$ differ only in their C-terminal sequences. FEBS Lett. 1987, 223, 138-142. [CrossRef] 
24. Ono, Y.; Fuji, T.; Ogita, K.; Kikkawa, U.; Igarashi, K.; Nishizuka, Y. Identification of three additional members of rat protein kinase C family: $\delta$-, $\epsilon$ - and $\xi$-subspecies. FEBS Lett. 1987, 226, 125-128. [CrossRef]

25. Osada, S.I.; Mizuno, K.; Saido, T.C.; Akita, Y.; Suzuki, K.; Kuroki, T.; Ohno, S. A phorbol ester receptor/protein kinase, nPKC eta, a new member of the protein kinase C family predominantly expressed in lung and skin. J. Biol. Chem. 1990, 265, 22434-22440. [CrossRef]

26. Steinberg, S.F. Structural basis of protein kinase C isoform function. Physiol. Rev. 2008, 88, 1341-1378. [CrossRef] [PubMed]

27. Takai, Y.; Kishimoto, A.; Kikkawa, U.; Mori, T.; Nishizuka, Y. Unsaturated diacylglycerol as a possible messenger for the activation of calcium-activated, phospholipid-dependent protein kinase system. Biochem. Biophys. Res. Commun. 1979, 91, 1218-1224. [CrossRef]

28. Castagna, M.; Takai, Y.; Kaibuchi, K.; Sano, K.; Kikkawa, U.; Nishizuka, Y. Direct activation of calcium-activated, phospholipiddependent protein kinase by tumor-promoting phorbol esters. J. Biol. Chem. 1982, 257, 7847-7851. [CrossRef]

29. Antal, C.E.; Hudson, A.M.; Kang, E.; Zanca, C.; Wirth, C.; Stephenson, N.L.; Trotter, E.W.; Gallegos, L.L.; Miller, C.J.; Furnari, F.B.; et al. Cancer-associated protein kinase C mutations reveal kinase's role as tumor suppressor. Cell 2015, 160, 489-502. [CrossRef]

30. Newton, A.C. Protein kinase C: Perfectly balanced. Crit. Rev. Biochem. Mol. Biol. 2018, 53, 208-230. [CrossRef]

31. Isakov, N. Protein kinase C (PKC) isoforms in cancer, tumor promotion and tumor suppression. Semin. Cancer Biol. 2018, 48, 36-52. [CrossRef]

32. Lahn, M.; Su, C.; Li, S.; Chedid, M.; Hanna, K.R.; Graff, J.R.; Sandusky, G.E.; Ma, D.; Niyikiza, C.; Sundell, K.L.; et al. Expression levels of protein kinase C- $\alpha$ in non-small-cell lung cancer. Clin. Lung Cancer 2004, 6, 184-189. [CrossRef] [PubMed]

33. Clark, A.S.; West, K.A.; Blumberg, P.M.; Dennis, P.A. Altered protein kinase C (PKC) isoforms in non-small cell lung cancer cells: PKC $\delta$ promotes cellular survival and chemotherapeutic resistance. Cancer Res. 2003, 63, 780-786. [PubMed]

34. Hirai, M.; Gamou, S.; Kobayashi, M.; Shimizu, N. Lung cancer cells often express high levels of protein kinase C activity. Jpn. J. Cancer Res. 1989, 80, 204-208. [CrossRef] [PubMed]

35. Jiang, H.; Fu, Q.; Song, X.; Ge, C.; Li, R.; Li, Z.; Zeng, B.; Li, C.; Wang, Y.; Xue, Y.; et al. HDGF and PRKCA upregulation is associated with a poor prognosis in patients with lung adenocarcinoma. Oncol. Lett. 2019, 18, 4936-4946. [CrossRef]

36. Wang, X.Y.; Repasky, E.; Liu, H.T. Antisense inhibition of protein kinase C $\alpha$ reverses the transformed phenotype in human lung carcinoma cells. Exp. Cell Res. 1999, 250, 253-263. [CrossRef]

37. Wang, C.; Wang, X.; Liang, H.; Wang, T.; Yan, X.; Cao, M.; Wang, N.; Zhang, S.; Zen, K.; Zhang, C.; et al. miR-203 inhibits cell proliferation and migration of lung cancer cells by targeting PKC $\alpha$. PLoS ONE 2013, 8, e73985. [CrossRef]

38. Dean, N.; McKay, R.; Miraglia, L.; Howard, R.; Cooper, S.; Giddings, J.; Nicklin, P.; Meister, L.; Ziel, R.; Geiger, T.; et al. Inhibition of growth of human tumor cell lines in nude mice by an antisense oligonucleotide inhibitor of protein kinase C- $\alpha$ expression. Cancer Res. 1996, 56, 3499-3507.

39. Deeds, L.; Teodorescu, S.; Chu, M.; Yu, Q.; Chen, C.Y. A p53-independent G1 cell cycle checkpoint induced by the suppression of protein kinase $C \alpha$ and $\theta$ isoforms. J. Biol. Chem. 2003, 278, 39782-39793. [CrossRef]

40. Singhal, S.S.; Wickramarachchi, D.; Singhal, J.; Yadav, S.; Awasthi, Y.C.; Awasthi, S. Determinants of differential doxorubicin sensitivity between SCLC and NSCLC. FEBS Lett. 2006, 580, 2258-2264. [CrossRef] [PubMed]

41. Singhal, S.S.; Yadav, S.; Singhal, J.; Awasthi, Y.C.; Awasthi, S. Mitogenic and drug-resistance mediating effects of PKC $\alpha$ require RLIP76. Biochem. Biophys. Res. Commun. 2006, 348, 722-727. [CrossRef] [PubMed]

42. Wang, X.Y.; Liu, H.T. Antisense expression of protein kinase $\mathrm{C}$ alpha improved sensitivity to anticancer drugs in human lung cancer LTEPa-2 cells. Acta Pharmacol. Sin. 1998, 19, 265-268.

43. Gao, Z.; Tang, L.; Su, B.; Sha, H.; Han, B. Effects of protein kinase C inhibitor, chelerythrine chloride, on drug-sensitivity of NSCLC cell lines. Chin. J. Lung Cancer 2007, 1, 455-460.

44. Sonnemann, J.; Gekeler, V.; Ahlbrecht, K.; Brischwein, K.; Liu, C.; Bader, P.; Müller, C.; Niethammer, D.; Beck, J.F. Down-regulation of protein kinase $\mathrm{C} \eta$ by antisense oligonucleotides sensitizes A549 lung cancer cells to vincristine and paclitaxel. Cancer Lett. 2004, 209, 177-185. [CrossRef] [PubMed]

45. Kang, J.H.; Mori, T.; Kitazaki, H.; Niidome, T.; Takayama, K.; Nakanishi, Y.; Katayama, Y. Kinase activity of protein kinase c $\alpha$ in serum as a diagnostic biomarker of human lung cancer. Anticancer Res. 2013, 33, 485-488.

46. Symonds, J.M.; Ohm, A.M.; Carter, C.J.; Heasley, L.E.; Boyle, T.A.; Franklin, W.A.; Reyland, M.E. Protein kinase C $\delta$ is a downstream effector of oncogenic K-ras in lung tumors. Cancer Res. 2011, 71, 2087-2097. [CrossRef]

47. Kim, E.H.; Lee, H.J.; Lee, D.H.; Bae, S.; Soh, J.W.; Jeoung, D.; Kim, J.; Cho, C.K.; Lee, Y.J.; Lee, Y.S. Inhibition of heat shock protein 27-mediated resistance to DNA damaging agents by a novel PKC delta-V5 heptapeptide. Cancer Res. 2007, 67, 6333-6341. [CrossRef]

48. Bae, K.M.; Wang, H.; Jiang, G.; Chen, M.G.; Lu, L.; Xiao, L. Protein Kinase Ce Is Overexpressed in Primary Human Non-Small Cell Lung Cancers and Functionally Required for Proliferation of Non-Small Cell Lung Cancer Cells in a p21/Cip1-Dependent Manner. Cancer Res. 2007, 67, 6053-6063. [CrossRef]

49. Totoń, E.; Ignatowicz, E.; Skrzeczkowska, K.; Rybczyńska, M. Protein kinase C $\varepsilon$ as a cancer marker and target for anticancer therapy. Pharmacol. Rep. 2011, 63, 19-29. [CrossRef]

50. Caino, M.C.; Lopez-Haber, C.; Kim, J.; Mochly-Rosen, D.; Kazanietz, M.G. Protein kinase C $\varepsilon$ is required for non-small cell lung carcinoma growth and regulates the expression of apoptotic genes. Oncogene 2012, 31, 2593-2600. [CrossRef] 
51. Caino, M.C.; Lopez-Haber, C.; Kissil, J.L.; Kazanietz, M.G. Non-small cell lung carcinoma cell motility, rac activation and metastatic dissemination are mediated by protein kinase C epsilon. PLoS ONE 2012, 7, e31714. [CrossRef]

52. Zhang, N.; Su, Y.; Xu, L. Targeting PKC $\varepsilon$ by miR-143 regulates cell apoptosis in lung cancer. FEBS Lett. 2013, 587, 3661-3667. [CrossRef]

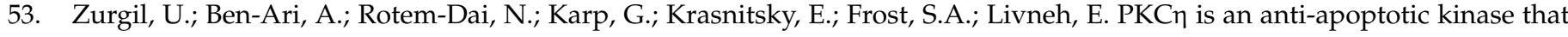
predicts poor prognosis in breast and lung cancer. Biochem. Soc. Trans. 2014, 42, 1519-1523. [CrossRef]

54. Krasnitsky, E.; Baumfeld, Y.; Freedman, J.; Sion-Vardy, N.; Ariad, S.; Novack, V.; Livneh, E. PKC $\eta$ is a novel prognostic marker in non-small cell lung cancer. Anticancer Res. 2012, 32, 1507-1513.

55. Basu, A. The Enigmatic Protein Kinase C-eta. Cancers 2019, 11, 214. [CrossRef]

56. Luo, Q.; Tang, L.; Lin, H.; Huang, J.; Zhang, T.; Liu, Y.; Wang, J.; Zhan, P.; Yin, X.; Su, X.; et al. The oncogenic role of PKCiota gene amplification and overexpression in Chinese non-small cell lung cancer. Lung Cancer 2014, 84, 190-195. [CrossRef]

57. Regala, R.P.; Weems, C.; Jamieson, L.; Khoor, A.; Edell, E.S.; Lohse, C.M.; Fields, A.P. Atypical protein kinase Cı is an oncogene in human non-small cell lung cancer. Cancer Res. 2005, 65, 8905-8911. [CrossRef]

58. Fields, A.P.; Regala, R.P. Protein kinase Ct: Human oncogene, prognostic marker and therapeutic target. Pharmacol. Res. 2007, 55, 487-497. [CrossRef]

59. BommaReddy, R.R.; Patel, R.; Smalley, T.; Acevedo-Duncan, M. Effects of atypical protein kinase C inhibitor (DNDA) on lung cancer proliferation and migration by PKC-ı/FAK ubiquitination through the Cbl-b pathway. OncoTargets Ther. 2020, 13, 1661. [CrossRef] [PubMed]

60. Kim, K.H.; Chung, C.; Kim, J.M.; Lee, D.; Cho, S.Y.; Lee, T.H.; Cho, H.J.; Yeo, M.K. Clinical significance of atypical protein kinase C (PKCᄂ and $\mathrm{PKC} \zeta$ ) and its relationship with yes-associated protein in lung adenocarcinoma. BMC Cancer 2019, 19, 804. [CrossRef]

61. Regala, R.P.; Weems, C.; Jamieson, L.; Copland, J.A.; Thompson, E.A.; Fields, A.P. Atypical protein kinase Cı plays a critical role in human lung cancer cell growth and tumorigenicity. J. Biol. Chem. 2005, 280, 31109-31115. [CrossRef] [PubMed]

62. Imamura, N.; Horikoshi, Y.; Matsuzaki, T.; Toriumi, K.; Kitatani, K.; Ogura, G.; Masuda, R.; Nakamura, N.; Takekoshi, S.; Iwazaki, M. Localization of aPKC lambda/iota and its interacting protein, Lgl2, is significantly associated with lung adenocarcinoma progression. Tokai J. Exp. Clin. Med. 2013, 38, 146-158.

63. Liu, L.; Lei, B.; Wang, L.; Chang, C.; Yang, H.; Liu, J.; Huang, G.; Xie, W. Protein kinase C-iota-mediated glycolysis promotes non-small-cell lung cancer progression. OncoTargets Ther. 2019, 12, 5835-5848. [CrossRef]

64. Erdogan, E.; Klee, E.W.; Thompson, E.A.; Fields, A.P. Meta-analysis of oncogenic protein kinase Cı signaling in lung adenocarcinoma. Clin. Cancer Res. 2009, 15, 1527-1533. [CrossRef] [PubMed]

65. Justilien, V.; Jameison, L.; Der, C.J.; Rossman, K.L.; Fields, A.P. Oncogenic activity of Ect2 is regulated through protein kinase Ct-mediated phosphorylation. J. Biol. Chem. 2011, 286, 8149-8157. [CrossRef] [PubMed]

66. Shultz, J.C.; Vu, N.; Shultz, M.D.; Mba, M.U.; Shapiro, B.A.; Chalfant, C.E. The Proto-oncogene PKCı regulates the alternative splicing of Bcl-x pre-mRNA. Mol. Cancer Res. 2012, 10, 660-669. [CrossRef] [PubMed]

67. Ali, S.A.; Justilien, V.; Jamieson, L.; Murray, N.R.; Fields, A.P. Protein kinase Cı drives a NOTCH3-dependent stem-like phenotype in mutant KRAS lung adenocarcinoma. Cancer Cell 2016, 29, 367-378. [CrossRef]

68. Fields, A.P.; Ali, S.A.; Justilien, V.; Murray, N.R. Targeting oncogenic protein kinase Cı for treatment of mutant KRAS LADC. Small GTPases 2017, 8, 58-64. [CrossRef] [PubMed]

69. Ito, M.; Codony-Servat, C.; Codony-Servat, J.; Lligé, D.; Chaib, I.; Sun, X.; Miao, J.; Sun, R.; Cai, X.; Verlicchi, A.; et al. Targeting PKCt-PAK1 signaling pathways in EGFR and KRAS mutant adenocarcinoma and lung squamous cell carcinoma. Cell Commun. Signal. 2019, 17, 137. [CrossRef]

70. Yin, N.; Liu, Y.; Khoor, A.; Wang, X.; Thompson, E.A.; Leitges, M.; Justilien, V.; Weems, C.; Murray, N.R.; Fields, A.P. Protein Kinase Cl and Wnt/ $\beta$-Catenin Signaling: Alternative Pathways to Kras/Trp53-Driven Lung Adenocarcinoma. Cancer Cell 2019, 36, 156-167. [CrossRef]

71. Liu, Y.; Wang, B.; Wang, J.; Wan, W.; Sun, R.; Zhao, Y.; Zhang, N. Down-regulation of PKCद expression inhibits chemotaxis signal transduction in human lung cancer cells. Lung Cancer 2009, 63, 210-218. [CrossRef] [PubMed]

72. Teicher, B.A.; Menon, K.; Alvarez, E.; Shih, C.; Faul, M.M. Antiangiogenic and antitumor effects of a protein kinase C $\beta$ inhibitor in human breast cancer and ovarian cancer xenografts. Investig. New Drugs 2002, 20, 241-251. [CrossRef] [PubMed]

73. Carmo, A.D.; Balça-Silva, J.; Matias, D.; Lopes, M. PKC signaling in glioblastoma. Cancer Biol. Ther. 2013, 14, 287-294. [CrossRef]

74. Kim, J.; Choi, Y.L.; Vallentin, A.; Hunrichs, B.S.; Hellerstein, M.K.; Peehl, D.M.; Mochly-Rosen, D. Centrosomal PKC $\beta I I$ and pericentrin are critical for human prostate cancer growth and angiogenesis. Cancer Res. 2008, 68, 6831-6839. [CrossRef]

75. Kazi, J.U.; Kabir, N.N.; Rönnstrand, L. Protein kinase C (PKC) as a drug target in chronic lymphocytic leukemia. Med. Oncol. 2013, 30, 757. [CrossRef]

76. Zum Bueschenfelde, C.M.; Wagner, M.; Lutzny, G.; Oelsner, M.; Feuerstacke, Y.; Decker, T.; Bogner, C.; Peschel, C.; Ringshausen, I. Recruitment of PKC- $\beta$ II to lipid rafts mediates apoptosis-resistance in chronic lymphocytic leukemia expressing ZAP-70. Leukemia 2010, 24, 141-152. [CrossRef]

77. Murray, N.R.; Baumgardner, G.P.; Burns, D.J.; Fields, A.P. Protein kinase C isotypes in human erythroleukemia (K562) cell proliferation and differentiation. Evidence that beta II protein kinase C is required for proliferation. J. Biol. Chem. 1993, 268, 15847-15853. [CrossRef] 
78. Lutzny, G.; Kocher, T.; Schmidt-Supprian, M.; Rudelius, M.; Klein-Hitpass, L.; Finch, A.J.; Dürig, J.; Wagner, M.; Haferlach, C.; Kohlmann, A.; et al. Protein kinase c- $\beta$-dependent activation of NF- $\mathrm{KB}$ in stromal cells is indispensable for the survival of chronic lymphocytic leukemia B cells in vivo. Cancer Cell 2013, 23, 77-92. [CrossRef] [PubMed]

79. Wetsel, W.C.; Khan, W.A.; Merchenthaler, I.; Rivera, H.; Halpern, A.E.; Phung, H.M.; Negro-Vilar, A.; Hannun, Y.A. Tissue and cellular distribution of the extended family of protein kinase C isoenzymes. J. Cell. Biol. 1992, 117, 121-133. [CrossRef] [PubMed]

80. Brezar, V.; Tu, W.J.; Seddiki, N. PKC-theta in regulatory and effector T-cell functions. Front. Immunol. 2015, 6, 530. [CrossRef] [PubMed]

81. Baier, G.; Telford, D.; Giampa, L.; Coggeshall, K.M.; Baier-Bitterlich, G.; Isakov, N.; Altman, A. Molecular cloning and characterization of PKC theta, a novel member of the protein kinase C (PKC) gene family expressed predominantly in hematopoietic cells. J. Biol. Chem. 1993, 268, 4997-5004. [CrossRef]

82. Abera, M.B.; Kazanietz, M.G. Protein kinase C $\alpha$ mediates erlotinib resistance in lung cancer cells. Mol. Pharmacol. 2015, 87, 832-841. [CrossRef] [PubMed]

83. He, M.; Yang, Z.; Le Zhang, C.S.; Li, Y.; Zhang, X. Additive effects of cherlerythrine chloride combination with erlotinib in human non-small cell lung cancer cells. PLoS ONE 2017, 12, e0175466.

84. Lee, P.C.; Fang, Y.F.; Yamaguchi, H.; Wang, W.J.; Chen, T.C.; Hong, X.; Ke, B.; Xia, W.; Wei, Y.; Zha, Z.; et al. Targeting PKC $\delta$ as a therapeutic strategy against heterogeneous mechanisms of EGFR inhibitor resistance in EGFR-mutant lung cancer. Cancer Cell 2018, 34, 954-969. [CrossRef]

85. Graff, J.R.; McNulty, A.M.; Hanna, K.R.; Konicek, B.W.; Lynch, R.L.; Bailey, S.N.; Banks, C.; Capen, A.; Goode, R.; Lewis, J.E.; et al. The protein kinase $C \beta$-selective inhibitor, enzastaurin $(\mathrm{LY} 317615$. $\mathrm{HCl})$, suppresses signaling through the AKT pathway, induces apoptosis, and suppresses growth of human colon cancer and glioblastoma xenografts. Cancer Res. 2005, 65, 7462-7469. [CrossRef]

86. Hanauske, A.R.; Oberschmidt, O.; Hanauske-Abel, H.; Lahn, M.M.; Eismann, U. Antitumor activity of enzastaurin (LY317615. $\mathrm{HCl}$ ) against human cancer cell lines and freshly explanted tumors investigated in vitro soft-agar cloning experiments. Investig. New Drugs 2007, 25, 205-210. [CrossRef]

87. Mukohara, T.; Nagai, S.; Koshiji, M.; Yoshizawa, K.; Minami, H. Phase I dose escalation and pharmacokinetic study of oral enzastaurin (LY317615) in advanced solid tumors. Cancer Sci. 2010, 101, 2193-2199. [CrossRef]

88. Carducci, M.A.; Musib, L.; Kies, M.S.; Pili, R.; Truong, M.; Brahmer, J.R.; Cole, P.; Sullivan, R.; Riddle, J.; Schimidt, J.; et al. Phase I dose escalation and pharmacokinetic study of enzastaurin, an oral protein kinase $\mathrm{C}$ beta inhibitor, in patients with advanced cancer. J. Clin. Oncol. 2006, 24, 4092-4099. [CrossRef]

89. Oh, Y.; Herbst, R.S.; Burris, H.; Cleverly, A.; Musib, L.; Lahn, M.; Bepler, G. Enzastaurin, an Oral Serine/Threonine Kinase Inhibitor, As Second- or Third-Line Therapy of Non-Small-Cell Lung Cancer. J. Clin. Oncol. 2008, 26, 1135-1141. [CrossRef]

90. Tekle, C.; Giovannetti, E.; Sigmond, J.; Graff, J.R.; Smid, K.; Peters, G.J. Molecular pathways involved in the synergistic interaction of the PKC $\beta$ inhibitor enzastaurin with the antifolate pemetrexed in non-small cell lung cancer cells. Br. J. Cancer 2008, 99, 750-759. [CrossRef]

91. Tanai, C.; Yamamoto, N.; Ohe, Y.; Takahashi, T.; Kunitoh, H.; Murakami, H.; Yamamoto, N.; Nakamura, Y.; Nokihara, H.; Shukuya, T.; et al. A phase I study of enzastaurin combined with pemetrexed in advanced non-small cell lung cancer. J. Thorac. Oncol. 2010, 5, 1068-1074. [CrossRef] [PubMed]

92. Chiappori, A.; Bepler, G.; Barlesi, F.; Soria, J.C.; Reck, M.; Bearz, A.; Barata, F.; Scagliotti, G.; Park, K.; Wagle, A.; et al. Phase II, double-blinded, randomized study of enzastaurin plus pemetrexed as second-line therapy in patients with advanced non-small cell lung cancer. J. Thorac. Oncol. 2010, 5, 369-375. [CrossRef]

93. Vansteenkiste, J.; Ramlau, R.; Von Pawel, J.; San Antonio, B.; Eschbach, C.; Szczesna, A.; Kennedy, L.; Visseren-Grul, C.; Chouaki, N.; Reck, M. A phase II randomized study of cisplatin-pemetrexed plus either enzastaurin or placebo in chemonaive patients with advanced non-small cell lung cancer. Oncology 2012, 82, 25-29. [CrossRef]

94. Socinski, M.A.; Raju, R.N.; Stinchcombe, T.; Kocs, D.M.; Couch, L.S.; Barrera, D.; Rousey, S.R.; Choksi, J.K.; Jotte, R.; Patt, D.A.; et al. Randomized, phase II trial of pemetrexed and carboplatin with or without enzastaurin versus docetaxel and carboplatin as first-line treatment of patients with stage IIIB/IV non-small cell lung cancer. J. Thorac. Oncol. 2010, 5, 1963-1969. [CrossRef]

95. Zhang, L.L.; Cao, F.F.; Wang, Y.; Meng, F.L.; Zhang, Y.; Zhong, D.S.; Zhou, Q.H. The protein kinase C (PKC) inhibitors combined with chemotherapy in the treatment of advanced non-small cell lung cancer: Meta-analysis of randomized controlled trials. Clin. Transl. Oncol. 2015, 17, 371-377. [CrossRef]

96. Newton, A.C.; Brognard, J. Reversing the Paradigm: Protein Kinase C as a Tumor Suppressor. Trends Pharmacol. Sci. 2017, 38, 438-447. [CrossRef]

97. Lu, Z.; Liu, D.; Hornia, A.; Devonish, W.; Pagano, M.; Foster, D.A. Activation of protein kinase C triggers its ubiquitination and degradation. Mol. Cell. Biol. 1998, 18, 839-845. [CrossRef]

98. Young, S.; Parker, P.J.; Ullrich, A.; Stabel, S. Down-regulation of protein kinase C is due to an increased rate of degradation. Biochem. J. 1987, 244, 775-779. [CrossRef]

99. Gescher, A.; Reed, D.J. Characterization of the growth inhibition induced by tumor-promoting phorbol esters and of their receptor binding in A549 human lung carcinoma cells. Cancer Res. 1985, 45, 4315-4321.

100. Dale, I.L.; Gescher, A. Effects of activators of protein kinase C, including bryostatins 1 and 2, on the growth of A549 human lung carcinoma cells. Int. J. Cancer 1989, 43, 158-163. [CrossRef] 
101. Dale, I.L.; Bradshaw, T.D.; Gescher, A.; Pettit, G.R. Comparison of effects of bryostatins 1 and 2 and 12-O-tetradecanoylphorbol13-acetate on protein kinase C activity in A549 human lung carcinoma cells. Cancer Res. 1989, 49, 3242-3245. [PubMed]

102. Bradshaw, T.D.; Gescher, A.; Pettit, G.R. Modulation by staurosporine of phorbol-ester-induced effects on growth and protein kinase C localization in A549 human lung-carcinoma cells. Int. J. Cancer 1992, 51, 144-148. [CrossRef] [PubMed]

103. Tanwell, C.S.; Gescher, A.; Bradshaw, T.D.; Pettit, G.R. The role of protein kinase $C$ isoenzymes in the growth inhibition caused by bryostatin 1 in human A549 lung and MCF-7 breast carcinoma cells. Int. J. Cancer 1994, 56, 585-592. [CrossRef] [PubMed]

104. Tahara, E.; Kadara, H.; Lacroix, L.; Lotan, D.; Lotan, R. Activation of protein kinase C by phorbol 12-myristate 13-acetate suppresses the growth of lung cancer cells through KLF6 induction. Cancer Biol. Ther. 2009, 8, 801-807. [CrossRef]

105. Xiao, L.; Caino, M.C.; von Burstin, V.A.; Oliva, J.L.; Kazanietz, M.G. Phorbol Ester-Induced Apoptosis and Senescence in Cancer Cell Models. Methods Enzymol. 2008, 446, 123-139.

106. Hornung, R.L.; Pearson, J.W.; Beckwith, M.; Longo, D.L. Preclinical evaluation of bryostatin as an anticancer agent against several murine tumor cell lines: In vitro versus in vivo activity. Cancer Res. 1992, 52, 101-107.

107. Winegarden, J.D.; Mauer, A.M.; Gajewski, T.F.; Hoffman, P.C.; Krauss, S.; Rudin, C.M.; Vokes, E.E. A phase II study of bryostatin-1 and paclitaxel in patients with advanced non-small cell lung cancer. Lung Cancer 2003, 39, 191-196. [CrossRef]

108. Geiger, T.; Müller, M.; Dean, N.M.; Fabbro, D. Antitumor activity of a PKC-alpha antisense oligonucleotide in combination with standard chemotherapeutic agents against various human tumors transplanted into nude mice. Anticancer Drug Des. 1998, 13, 35-45.

109. Villalona-Calero, M.A.; Ritch, P.; Figueroa, J.A.; Otterson, G.A.; Belt, R.; Dow, E.; George, S.; Leonardo, J.; McCachren, S.; Miller, G.L.; et al. A Phase I/II study of LY900003, an antisense inhibitor of protein kinase C- $\alpha$, in combination with cisplatin and gemcitabine in patients with advanced non-small cell lung cancer. Clin. Cancer Res. 2004, 10, 6086-6093. [CrossRef]

110. Ritch, P.; Rudin, C.M.; Bitran, J.D.; Edelman, M.J.; Makalinao, A.; Irwin, D.; Lilenbaum, R.; Peterson, P.; John, W.J. Phase II study of PKC- $\alpha$ antisense oligonucleotide aprinocarsen in combination with gemcitabine and carboplatin in patients with advanced non-small cell lung cancer. Lung Cancer 2006, 52, 173-180. [CrossRef]

111. Lynch, T.J.; Raju, R.; Lind, M.; Riviere, A.; Gatzemeier, U.; Dorr, A.; Holmund, J.; Yuen, A.; Sikic, B. Randomized phase III trial of chemotherapy and antisense oligonucleotide LY900003 (ISIS 3521) in patients with advanced NSCLC. Lung Cancer 2003, 41, S35. [CrossRef]

112. Paz-Ares, L.; Douillard, J.Y.; Koralewski, P.; Manegold, C.; Smit, E.F.; Reyes, J.M.; Chang, G.; John, W.J.; Peterson, P.M.; Obasaju, C.K.; et al. Phase III study of gemcitabine and cisplatin with or without aprinocarsen, a protein kinase C-alpha antisense oligonucleotide, in patients with advanced-stage non-small-cell lung cancer. J. Clin. Oncol. 2006, 24, 1428-1434. [CrossRef] [PubMed]

113. Salama, M.F.; Liu, M.; Clarke, C.J.; Espaillat, M.P.; Haley, J.D.; Jin, T.; Wang, D.; Obeid, L.M.; Hannun, Y.A. PKC $\alpha$ is required for Akt-mTORC1 activation in non-small cell lung carcinoma (NSCLC) with EGFR mutation. Oncogene 2019, 38, 7311-7328. [CrossRef]

114. Mochly-Rosen, D.; Das, K.; Grimes, K.V. Protein kinase C, an elusive therapeutic target? Nat. Rev. Drug Discov. 2012, 11, 937-957. [CrossRef] 